[Article]

\title{
纳米三氧化铇复合催化剂的制备及对甲醇电催化性能
}

\author{
周阳 ${ }^{1,2}$ 刘委明 ${ }^{1}$ 胡仙超 ${ }^{1,3}$ 禇有群 ${ }^{1}$ 马淳安 ${ }^{1, *}$ \\ ('浙江工业大学化工材料学院, 绿色化学合成技术国家重点实验室培育基地, 科技部能源材料及应用国际科技合作基地, \\ 杭州 310032; 2江西理工大学冶金与化学工程学院, 江西 赣州 341000； 3 浙江工业大学分析测试中心, 杭州 310032)
}

\begin{abstract}
摘要: 采用浸渍沉淀法制备出 $\mathrm{WO}_{3}$-碳纳米管 $\left(\mathrm{WO}_{3}-\mathrm{CNTS}\right)$ 纳米复合材料, 微波辅助乙二醇法在其表面负载活 性成分 $P t$, 得到纳米 $P t / W O_{3}-C N T s$ 催化剂. 采用 $X$ 射线衍射 (XRD), 透射电子显微镜(TEM)和 $X$ 射线光电子能 谱(XPS)等测试手段对催化剂的结构和形貌进行表征, 结果表明 Pt 纳米粒子为面心立方晶体结构, 粒径大小在 3-5 nm 之间, 均匀地分布在 $\mathrm{WO}_{3}-\mathrm{CNTS}$ 纳米复合材料表面, 同时发现催化剂中的 $\mathrm{Pt}$ 主要以金属态的形式存 在. 采用循环伏安和计时电流法研究了在酸性溶液中 $\mathrm{Pt} / \mathrm{WO}_{3}-\mathrm{CNTS}$ 催化剂对甲醇的电催化氧化性能, 结果表 明 $\mathrm{Pt} / \mathrm{WO}_{3}-\mathrm{CNTs}$ 催化剂比用硝酸处理的碳纳米管载铂催化剂(Pt/CNTs)对甲醇呈现出更高的电催化氧化活性 和抗 $\mathrm{CO}$ 中毒性能.
\end{abstract}

关键词：直接甲醇燃料电池; 碳纳米管; 三氧化铇; 电催化 中图分类号: 0646

\section{Nano- $\mathrm{WO}_{3}$ Composite Materials as Electro-Catalyst for Methanol Oxidation}

\author{
ZHOU Yang ${ }^{1,2} \quad$ LIU Wei-Ming ${ }^{1} \quad$ HU Xian-Chao ${ }^{1,3} \quad$ CHU You-Qun ${ }^{1} \quad$ MA Chun-An ${ }^{1, *}$ \\ ('State Key Laboratory Breeding Base for Green Chemistry Synthesis Technology, International Science \& Technology Cooperation \\ Base of Energy Materials and Application, College of Chemical Engineering and Materials Science, Zhejiang University of \\ Technology, Hangzhou 310032, P. R. China; ${ }^{2}$ Metallurgical and Chemical Engineering Institute, Jiangxi University of Science and \\ Technology, Ganzhou 341000, Jiangxi Province, P. R. China; ${ }^{3}$ Research Center of Analysis and Measurement, \\ Zhejiang University of Technology, Hangzhou 310032, P. R. China)
}

\begin{abstract}
Nano- $\mathrm{WO}_{3}$ modified carbon nanotube supported Pt nanoparticles ( $\left.\mathrm{Pt} / \mathrm{WO}_{3}-\mathrm{CNTs}\right)$ with uniform dimension were prepared by impregnated precipitation method, and $\mathrm{Pt}$ nanoparticles were loaded on the surface of $\mathrm{WO}_{3}$-CNTs by means of microwave-assisted glycol method. X-ray powder diffraction (XRD) and transmission electron microscopy (TEM) reveal that the Pt nanoparticles have a face-centered cubic crystal structure and are highly dispersed on the surface of $\mathrm{WO}_{3}$-modified CNTs with a narrow size distribution between 3 and $5 \mathrm{~nm}$. X-ray photoelectron spectroscopy (XPS) shows that more metallic $\mathrm{Pt}$ is present on $\mathrm{Pt} /$ $\mathrm{WO}_{3}$-CNTs than on Pt/CNTs catalyst. Compared with the Pt/CNTs catalyst without $\mathrm{WO}_{3}$ modification, the Pt/ $\mathrm{WO}_{3}$-CNTs composite catalyst not only shows relative large electrochemical active surface area, high catalyst activity toward methanol electro-oxidation, but also exhibits very high stability with apparent antiposion tolerance to the incomplete oxidized species during methanol oxidation.
\end{abstract}

Key Words: Direct methanol fuel cell; Carbon nanotube; Tungsten trioxide; Electro-catalysis

\footnotetext{
Received: December 17, 2012; Revised: April 11, 2013; Published on Web: April 12, 2013.

"Corresponding author. Email: science@zjut.edu.cn; Tel: +86-571-88320360.

The project was supported by the International Science \& Technology Cooperation Program of China (2010DFB63680), Zhejiang Ministry of Education Foundation, China (Y201225711), and Key Project of Natural Science Foundation of Zhejiang Province, China (Z4100790). 科技部国际科技合作重大专项(2010DFB63680), 浙江省教育厅科研项目(Y201225711)和浙江省自然科学基金重点项目(Z4100790)资助 C. Editorial office of Acta Physico-Chimica Sinica
} 


\section{Introduction}

Direct methanol fuel cells (DMFCs) have recently attracted considerable attentions due to their excellent features such as high-energy density, convenient fuel storage, green emission, and ambient operating conditions etc. ${ }^{1,2}$ However, DMFCs usually use lots of expensive platinum as anodic catalysts that tend to be poisoned by reaction intermediates such as $\mathrm{CO}_{\text {ads. }}{ }^{3}$ Thus considerable efforts have been devoted to making metallic alloy, such as PtRu, ${ }^{4,5} \mathrm{PtPd}^{6,7}$ and $\mathrm{PtRuSn}{ }^{8,9}$ etc., with low amount of platinum and high activity toward methanol oxidation. But the dissolution of transition metals in the alloys during the DMFC operation would be the main challenge since the dissolved transition metals may span the membrane and experience reduction on the cathode, finally leading to the unexpected performance degradation of DMFCs. ${ }^{10,11}$

The second way to design Pt-based composite catalysts is metal oxides modified Pt particles, such as $\mathrm{Pt} / \mathrm{RuO}_{2},{ }^{12,13} \mathrm{Pt} / \mathrm{SnO}_{2},{ }^{14,15}$ and $\mathrm{Pt} / \mathrm{MnO}_{2}{ }^{16}{ }^{16}$ etc. Tungsten trioxide $\left(\mathrm{WO}_{3}\right)$ is known to be able to form a hydrogen tungsten bronze $\left(\mathrm{H}_{x} \mathrm{WO}_{3}\right)$ compound in acid solution which is both nonstoichiometric and electrically conducting. The compound can facilitate dehydrogenation during methanol oxidation and lighten the $\mathrm{CO}$ poisoning of $\mathrm{Pt}$ catalyst. Previous studies have shown that Pt and PtRu catalysts supported on $\mathrm{WO}_{3}$ have extremely high activity towards the electro-oxidation of $\mathrm{CO},{ }^{17}$ methanol, ${ }^{18-21}$ ethanol, ${ }^{22}$ and formic acid. ${ }^{23,24}$ However, $\mathrm{WO}_{3}$ has a low specific surface area and conductivity, which limits its application in DMFC.

Recently $\mathrm{WO}_{3} / \mathrm{C}$ hybrid material was used as the support of Pt- $\mathrm{WO}_{3} / \mathrm{C}$ catalysts. ${ }^{25,26}$ Compared with Vulcan XC-72 carbon black, carbon nanotubes (CNTs) have better specific surface area and conductivity. Rajesh et l. $^{27}$ reported a composite catalyst of methanol electro-oxidation by depositing Pt nanoparticles on $\mathrm{WO}_{3}$-modified $\mathrm{CNT}$, in which $\mathrm{CNT}$ was synthesised by the template carbonisation of polypyrrole on alumina membrane. In this paper CNT was further disposed by strong acid so that $\mathrm{Pt}$ and $\mathrm{WO}_{3}$ nanoparticles were homogenously deposited on the surface of CNT. Results show that $\mathrm{WO}_{3}$-modification improves significantly electrocatalytic activity towards methanol oxidation.

\section{Experimental}

\subsection{Preparation of $\mathrm{WO}_{3}$ modified acid treated CNTs}

Carbon nanotubes (Shenzhen Nanoharbor Co., China) were functionalized in nitric acid $(65 \%-68 \%)$ under refluxing at $150{ }^{\circ} \mathrm{C}$ for $5 \mathrm{~h}$, washed by distilled water and dried in vacuum at $85{ }^{\circ} \mathrm{C}^{28} \mathrm{WO}_{3}$-modified carbon nanotubes $\left(\mathrm{WO}_{3}-\mathrm{CNTs}\right)$ were prepared by the conventional means with sodium tungstate as the precursor. Briefly, $50 \mathrm{mg}$ of CNTs was added into $5 \mathrm{mmol}$. $\mathrm{L}^{-1}$ aqueous solution of sodium tungstate. After ultrasonic dispersed for $30 \mathrm{~min}$, the solution were stirred vigorously at $60{ }^{\circ} \mathrm{C}$ for $1 \mathrm{~h}$, then excessive $1 \mathrm{~mol} \cdot \mathrm{L}^{-1}$ hydrochloric acid was dropwised into the above solution. After the reaction proceeded for $6 \mathrm{~h}$, the suspension was filtered, washed and dried at $80^{\circ} \mathrm{C}$ in a vacuum oven. The resultant was transferred into a tubular oven and heat-treated at $500{ }^{\circ} \mathrm{C}$ for $6 \mathrm{~h}$ under the protection of a nitrogen atmosphere. The ideal ratio of $\mathrm{WO}_{3}$ to CNTs was calculated as $25 \%(w)$, but for comparison, ratio of $\mathrm{WO}_{3}$ to CNTs with $10 \%, 25 \%, 50 \%$, and $75 \%(w)$ were also prepared following same procedures as above.

\subsection{Synthesis of Pt nanoparticles on $\mathrm{WO}_{3}-\mathrm{CNTs}$}

Platinum supported on the $\mathrm{WO}_{3}$-modified $\mathrm{CNTs}\left(\mathrm{Pt} / \mathrm{WO}_{3}\right.$ CNTs) was prepared by means of microwave heating ethylene glycol method. In brief, $5.7 \mathrm{~mL}$ of $5 \mathrm{mmol} \cdot \mathrm{L}^{-1}$ chloroplatinic acid was well mixed with $15 \mathrm{~mL}$ ethylene glycol (EG) in a special reaction tube, and then $50.0 \mathrm{mg}$ of as-prepared $\mathrm{WO}_{3} / \mathrm{CNTs}$ was added into the mixture. After the $\mathrm{pH}$ of the mixture was adjusted to 10 using $1.0 \mathrm{~mol} \cdot \mathrm{L}^{-1} \mathrm{NaOH}$ aqueous, well-dispersed slurry was obtained after being stirred in an ultrasonic bath for $30 \mathrm{~min}$. Thereafter, the slurry was microwave-heated at $160^{\circ} \mathrm{C}$ for $30 \mathrm{~min}$ in the microwave synthesizer (Initiator Biotage, Sweden). The resulting solution was filtered, washed and dried at $85{ }^{\circ} \mathrm{C}$ for $10 \mathrm{~h}$ in a vacuum oven, yielding $10 \%(w) \mathrm{Pt}$ loading on the supports. As contrast samples, Pt nanoparticles $(10 \%(w)$ metal content) on acid treated CNTs (Pt/CNTs) was prepared using similar procedures as described above.

\subsection{Characterizations}

The morphology, crystal phase, structure and element distribution of the samples were respectively characterized by XRD, XPS, and TEM. XRD was performed with a Thermo ARL SCINTAG X'TRA X-ray at room temperature, using quartz monochromatic $\mathrm{Cu} K_{\alpha 1}$ radiation source $(\lambda=0.1541 \mathrm{~nm})$ under a voltage of $45 \mathrm{kV}$ and a current of $40 \mathrm{~mA}$. The XRD patterns were recorded with a step size of $0.04^{\circ}$ from $10^{\circ}$ to $80^{\circ}$ at the speed of $2.4\left({ }^{\circ}\right) \cdot \mathrm{min}^{-1}$. TEM was carried out on a Tecnai G2 F30 S-Twin (Philips-FEI). XPS was carried out on Kratos AXIS Ultra DLD.

\subsection{Electrochemical measurements}

Electrochemical measurements were performed on Ivium electrochemical workstation. A standard three-electrode cell with separate anode and cathode compartments was used. A Pt foil and saturated calomel electrode (SCE) were used as counter and reference electrodes, respectively. For electrode preparation, $2.5 \mathrm{mg}$ of electrocatalyst sample was ultrasonically mixed in $400 \mu \mathrm{L}$ of ethanol-water solution $(1: 1, V / V)$ to form a homogeneous ink followed by dropping $5 \mu \mathrm{L}$ of the electrocatalyst ink onto the surface of a glassy carbon electrode (GCE, with a diameter of $3 \mathrm{~mm}$ ), and $7 \mu \mathrm{L}$ of Nafion solution of $1.0 \%$ (DuPont, USA) in ethanol was added to fix the electrocatalyst on the GCE surface. The electrochemical active surface (EAS) assessed in a nitrogen-saturated $0.5 \mathrm{~mol} \cdot \mathrm{L}^{-1} \mathrm{H}_{2} \mathrm{SO}_{4}$ solution at a scan rate of $50 \mathrm{mV} \cdot \mathrm{s}^{-1}$ and the electrocatalytic activity for the methanol oxidation reaction was measured in a nitrogensaturated $0.5 \mathrm{~mol} \cdot \mathrm{L}^{-1} \mathrm{H}_{2} \mathrm{SO}_{4}+1.0 \mathrm{~mol} \cdot \mathrm{L}^{-1} \mathrm{CH}_{3} \mathrm{OH}$ solution at a scan rate of $50 \mathrm{mV} \cdot \mathrm{s}^{-1}$.

The CO stripping experiments were performed in a $0.5 \mathrm{~mol}$. $\mathrm{L}^{-1} \mathrm{H}_{2} \mathrm{SO}_{4}$ solution. Along with the continuous $\mathrm{CO}$ bubbling for 
$30 \mathrm{~min}$, the anode electrode was controlled at $-0.14 \mathrm{~V}$ for $\mathrm{CO}$ adsorption. The solution was then purged with $\mathrm{N}_{2}$ for $30 \mathrm{~min}$ to remove the dissolved $\mathrm{CO}$ before the stripping test.

\section{Results and discussion}

\subsection{XRD and TEM analysis of samples}

Fig. 1 shows the typical XRD patterns of the samples. The diffraction peak at $2 \theta=26.2^{\circ}$ is characteristic of the graphite (002) plane, demonstrating the graphitization of carbon in the sample. The distinct diffraction peaks at $2 \theta$ of $23.09^{\circ}, 23.58^{\circ}$, $24.33^{\circ}, 33.25^{\circ}, 34.12^{\circ}$, and $41.44^{\circ}$ are indexed as the $(002)$, (020), (200), (022), (202), and (222) planes of monoclinic $\mathrm{WO}_{3}$ phase..$^{29}$ Those slight diffraction peaks at $2 \theta$ of $39.76^{\circ}, 46.28^{\circ}$, and $67.53^{\circ}$ are attributed to the Pt (111), (200), and (220) planes, which are not obvious for $\mathrm{Pt} / \mathrm{WO}_{3}-\mathrm{CNTs}$, indeed, the broaden peak centered at $41.45^{\circ}$ is the overlapped peak of the (111) peak of Pt and the (222) peak of $\mathrm{WO}_{3}$.

Fig.2 shows scanning transmission electron microscope

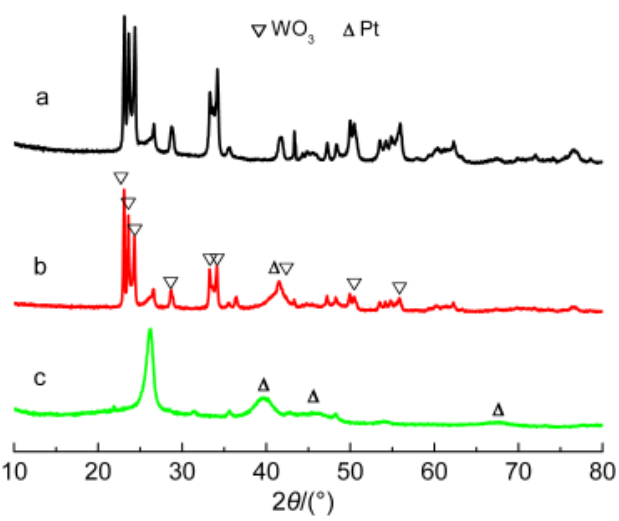

Fig.1 XRD patterns of (a) $\mathrm{WO}_{3}$-CNTs, (b) $\mathrm{Pt} / \mathrm{WO}_{3}$-CNTs, and (c) Pt/CNTs catalysts
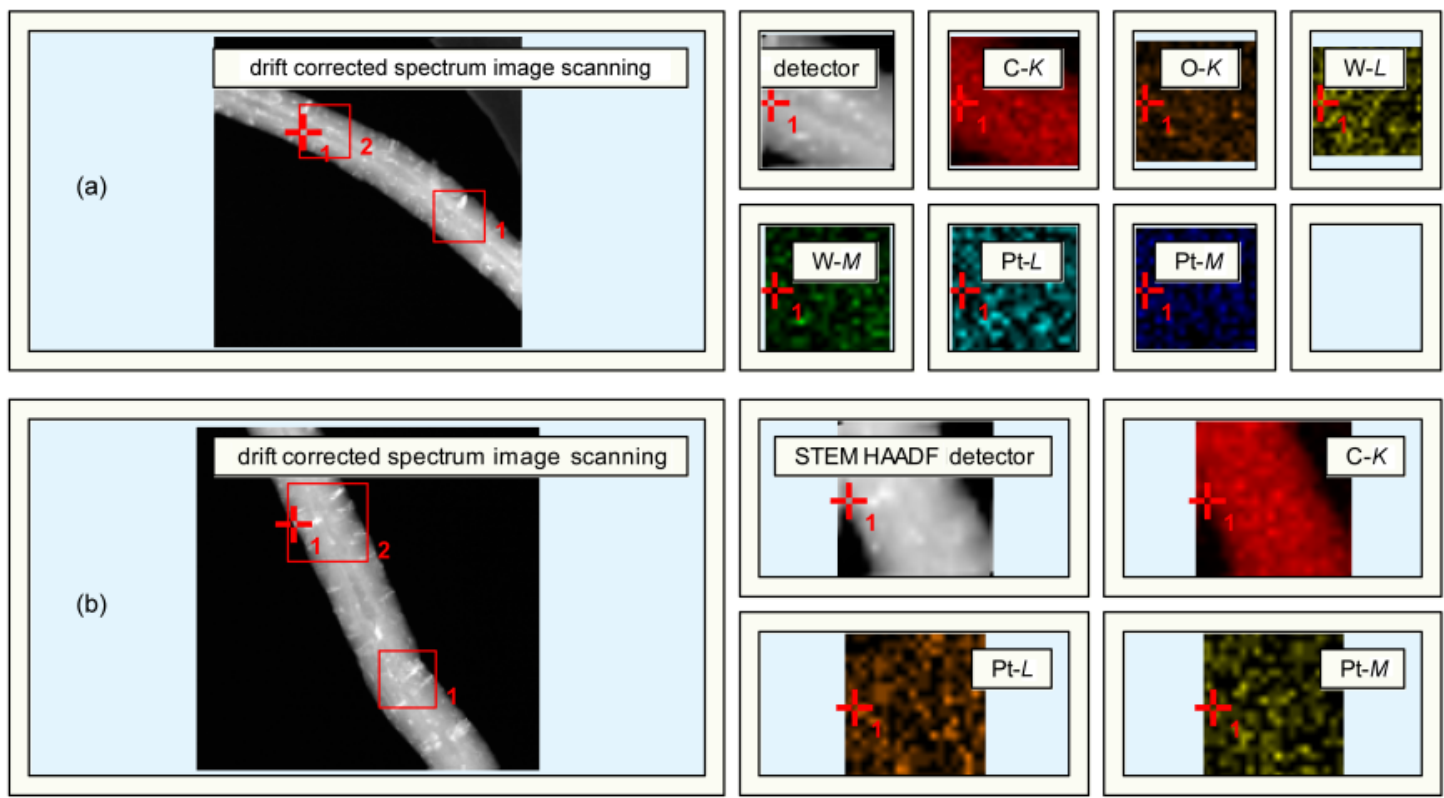

Fig.2 EDS elemental mapping of (a) $\mathrm{Pt}_{\text {-WO }}$-CNTs and (b) Pt/CNTs catalysts under STEM model 

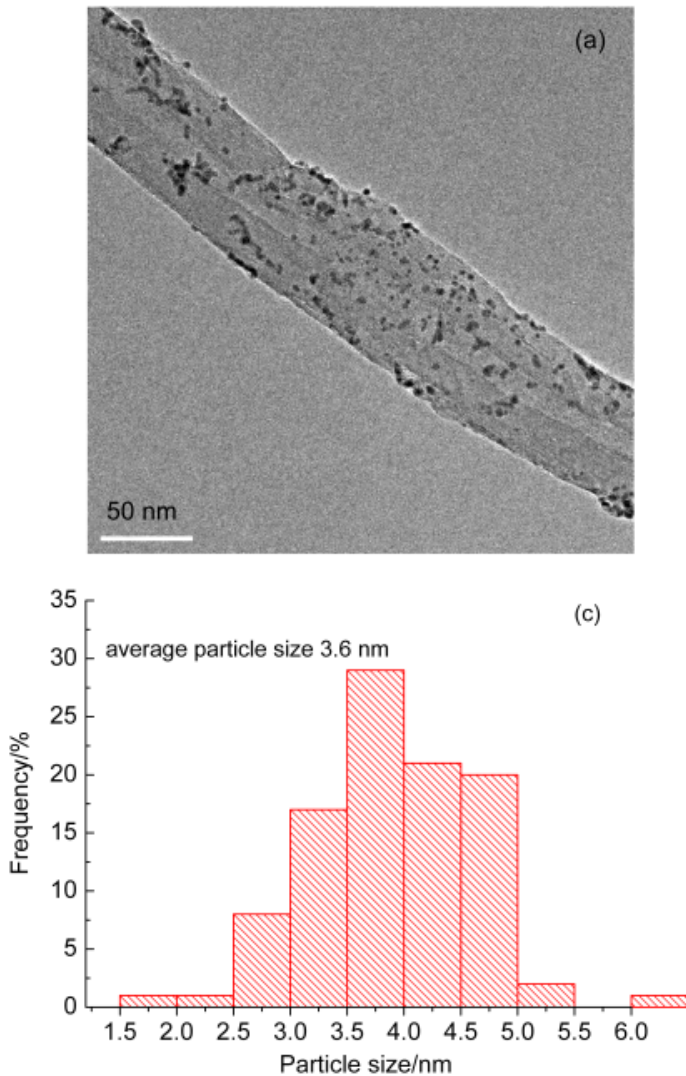
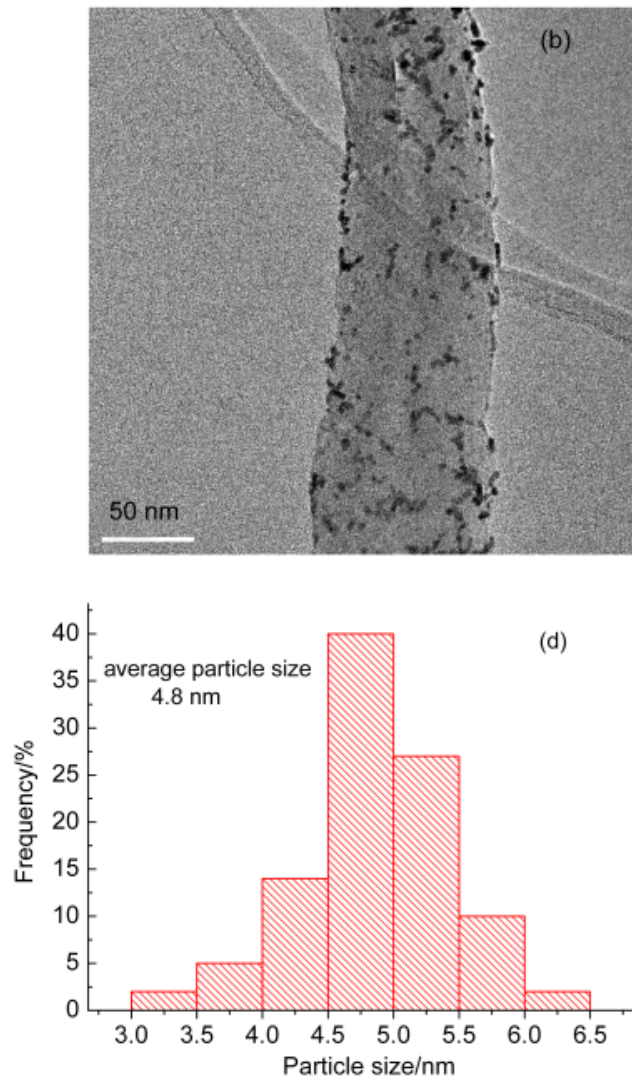

Fig.3 TEM images of (a) Pt/WO $\mathrm{W}_{3}-\mathrm{CNTs}$ and (b) Pt/CNTs, and Pt particle size distributions of (c) $\mathrm{Pt} / \mathrm{WO}_{3}-\mathrm{CNTs}$ and (d) Pt/CNTs
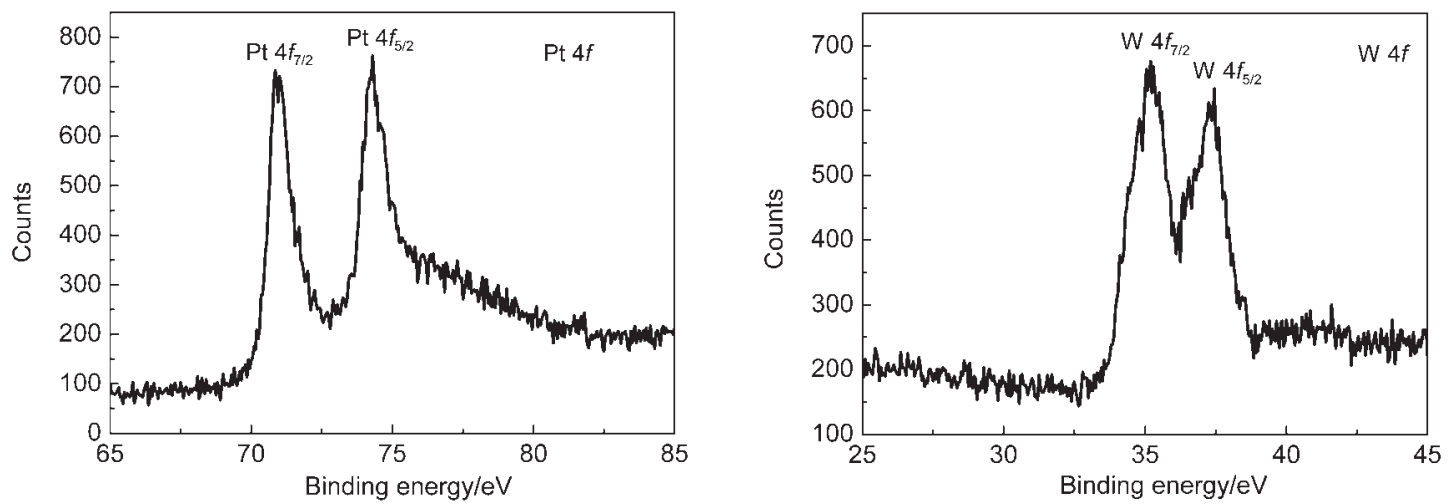

Fig.4 XPS spectra of the $\mathrm{Pt} 4 f$ and $\mathrm{W} 4 \mathrm{f}$ photoemission from $\mathrm{Pt} / \mathrm{WO}_{3}-\mathrm{CNTs}$

than that in Pt/CNTs, which is reflected by the hydrogen adsorption/desorption currents at the potentials between -0.2 and $0.2 \mathrm{~V}$, as shown in Fig.6. The EAS of platinum can be calculated from the integrated charge in the hydrogen adsorption region of the cyclic voltammograms (Fig.6) based on ESA $=Q_{\mathrm{H}} /$ $0.21 \times[\mathrm{Pt}]$, where $Q_{\mathrm{H}}$ is the integrated charge $(\mathrm{mC}),[\mathrm{Pt}]$ is the Pt loading $\left(\mathrm{mg} \cdot \mathrm{cm}^{-2}\right)$ on the electrode. The EAS values calculated for $\mathrm{Pt} / \mathrm{CNTs}$ and $\mathrm{Pt} / \mathrm{WO}_{3}-\mathrm{CNTs}$ are shown in Table 1 , which reveals that the EAS of platinum is influenced by the particle sizes. This result is consistent with Pt particle size distributions of $\mathrm{Pt} / \mathrm{CNTs}$ and $\mathrm{Pt} / \mathrm{WO}_{3}-\mathrm{CNTs}$ (Fig.3).

Fig. 7 shows $\mathrm{CVs}$ of the electrodes in $0.5 \mathrm{~mol} \cdot \mathrm{L}^{-1} \mathrm{H}_{2} \mathrm{SO}_{4}+1$ $\mathrm{mol} \cdot \mathrm{L}^{-1} \mathrm{CH}_{3} \mathrm{OH}$ solution between 0.0 to $1.0 \mathrm{~V}$ at a scan rate of
$50 \mathrm{mV} \cdot \mathrm{s}^{-1}$. The electrocatalytic activity of $\mathrm{Pt} / \mathrm{WO}_{3}-\mathrm{CNTs}$ and $\mathrm{Pt} / \mathrm{CNTs}$ catalysts on the oxidation of methanol was studied in $0.5 \mathrm{~mol} \cdot \mathrm{L}^{-1} \mathrm{H}_{2} \mathrm{SO}_{4}$ aqueous solution containing $1.0 \mathrm{~mol} \cdot \mathrm{L}^{-1}$ $\mathrm{CH}_{3} \mathrm{OH}$ at a scan rate of $50 \mathrm{mV} \cdot \mathrm{s}^{-1}$. It can be observed from Fig.7 that the onset of methanol oxidation peaks for the $\mathrm{Pt} /$ $\mathrm{WO}_{3}$-CNTs catalyst is at $0.25 \mathrm{~V}$, which is apparently lower than that on $\mathrm{Pt} / \mathrm{CNT}$ catalysts with the onsets at $0.30 \mathrm{~V}$. The negative shift on the potential onset of $\mathrm{Pt} / \mathrm{WO}_{3}-\mathrm{CNTs}$ indicates that $\mathrm{Pt}$ nanoparticles on $\mathrm{WO}_{3}-\mathrm{CNTs}$ surface can effectively reduce the over potentials in the methanol electro-oxidation reaction. In addition, it can be seen that the mass specific current of $\mathrm{Pt} / \mathrm{WO}_{3}-\mathrm{CNTs}\left(403 \mathrm{~mA} \cdot \mathrm{mg}^{-1}\right)$ is 5 times that of $\mathrm{Pt} / \mathrm{CNT}(80$ $\mathrm{mA} \cdot \mathrm{mg}^{-1}$ ) at $0.69 \mathrm{~V}$, indicating that $\mathrm{WO}_{3}$ plays a key role in 


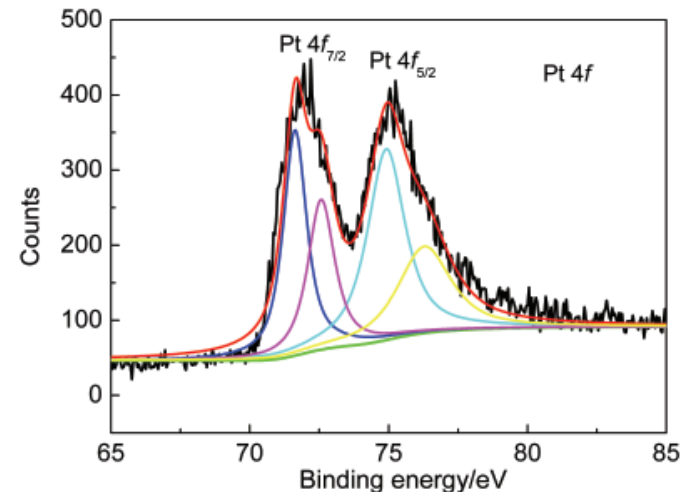

Fig.5 XPS spectra of the Pt $4 f$ photoemission from Pt/CNTs

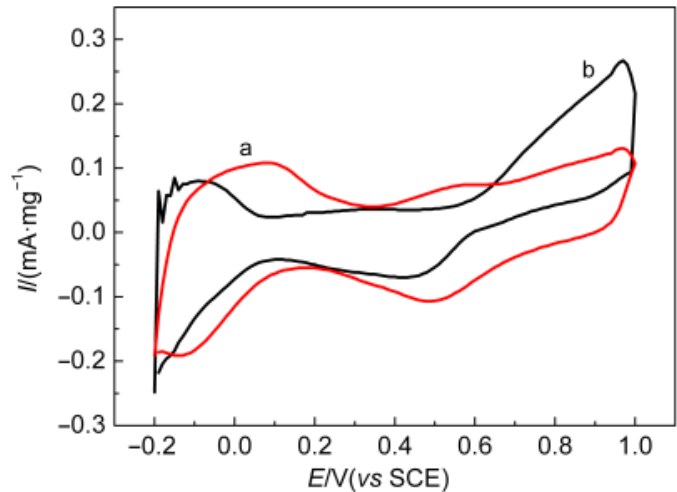

Fig.6 Cyclic voltammograms of (a) $\mathrm{Pt} / \mathrm{WO}_{3}$-CNTs and (b) $\mathrm{Pt} / \mathrm{CNTs}$ in $0.5 \mathrm{~mol} \cdot \mathrm{L}^{-1} \mathrm{H}_{2} \mathrm{SO}_{4}$ solution at a scan rate of $50 \mathrm{mV} \cdot \mathrm{s}^{-1}$

Table 1 Onset potential, EAS, peak current density, and forward anodic to reverse anodic peak current density ratio of the different catalysts for methanol oxidation

\begin{tabular}{ccccc}
\hline Catalyst & Onset potential $/ \mathrm{mV}$ & $\mathrm{EAS} /\left(\mathrm{m}^{2} \cdot \mathrm{g}^{-1}\right)$ & $I_{\max } /\left(\mathrm{mA} \cdot \mathrm{mg}^{-1}\right)$ & $I_{\mathrm{t}} / I_{\mathrm{b}}$ \\
\hline $\mathrm{Pt} / \mathrm{WO}_{3}$-CNTs & 0.25 & 26.0 & 403 & 1.37 \\
$\mathrm{Pt} / \mathrm{CNTs}$ & 0.30 & 13.4 & 80 & 0.96 \\
\hline
\end{tabular}

the high catalytic performance.

Besides, it is well known that the ratio of the forward anodic peak current density $\left(I_{\mathrm{f}}\right)$ to the reverse anodic peak current density $\left(I_{\mathrm{b}}\right)$, i.e., $I_{\mathrm{f}} / I_{\mathrm{b}}$, suggests a tolerance to carbonaceous species accumulation of catalysts during methanol electro-oxidation. And the high $I_{\mathrm{f}} / I_{\mathrm{b}}$ indicates excellent oxidation of methanol during the reverse anodic scan and less accumulation of residues on the catalyst. Here the $I_{\mathrm{f}} / I_{\mathrm{b}}$ ratio for $\mathrm{Pt} / \mathrm{WO}_{3}-\mathrm{CNT}$ is about 1.37, which is much higher than that of $\mathrm{Pt} / \mathrm{CNT}$ catalyst (0.96), showing the $\mathrm{Pt} / \mathrm{WO}_{3}-\mathrm{CNT}$ has a better tolerance to carbonaceous species accumulation.

Fig.8(a) shows the cyclic voltammograms of $\mathrm{Pt} / \mathrm{WO}_{3}-\mathrm{CNTs}$ catalyst with different mass contents of $\mathrm{WO}_{3}$ in $0.5 \mathrm{~mol} \cdot \mathrm{L}^{-1}$ $\mathrm{H}_{2} \mathrm{SO}_{4}+1.0 \mathrm{~mol} \cdot \mathrm{L}^{-1} \mathrm{CH}_{3} \mathrm{OH}$ solution. In Fig.8(b), the effects of $\mathrm{WO}_{3}$ content on the anodic peak current density and the $I_{\mathrm{f}} / I_{\mathrm{b}}$ ratio are shown. It can be seen that for $\mathrm{Pt} / \mathrm{WO}_{3}-\mathrm{CNTs}$ catalyst, the peak current density of methanol oxidation increases along with the increasing of $\mathrm{WO}_{3}$ content because $\mathrm{WO}_{3}$ reduces the $\mathrm{Pt}$ nanoparticles size and improves the dispersion of $\mathrm{Pt}$ nanoparticles on the surface of CNTs. ${ }^{26}$ However, the increas-

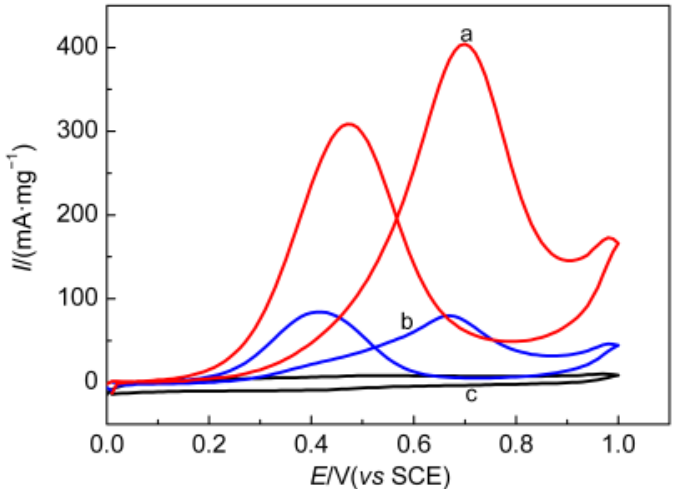

Fig.7 Cyclic voltagrammograms of methanol oxidation on (a) $\mathrm{Pt} / \mathrm{WO}_{3}-\mathrm{CNTs}$, (b) $\mathrm{Pt} / \mathrm{CNTs}$, and (c) $\mathrm{WO}_{3} / \mathrm{CNTs}$ in $0.5 \mathrm{~mol} \cdot \mathrm{L}^{-1}$ $\mathrm{H}_{2} \mathrm{SO}_{4}+1 \mathrm{~mol} \cdot \mathrm{L}^{-1} \mathrm{CH}_{3} \mathrm{OH}$ solution at a scan rate of $50 \mathrm{mV} \cdot \mathrm{s}^{-1}$
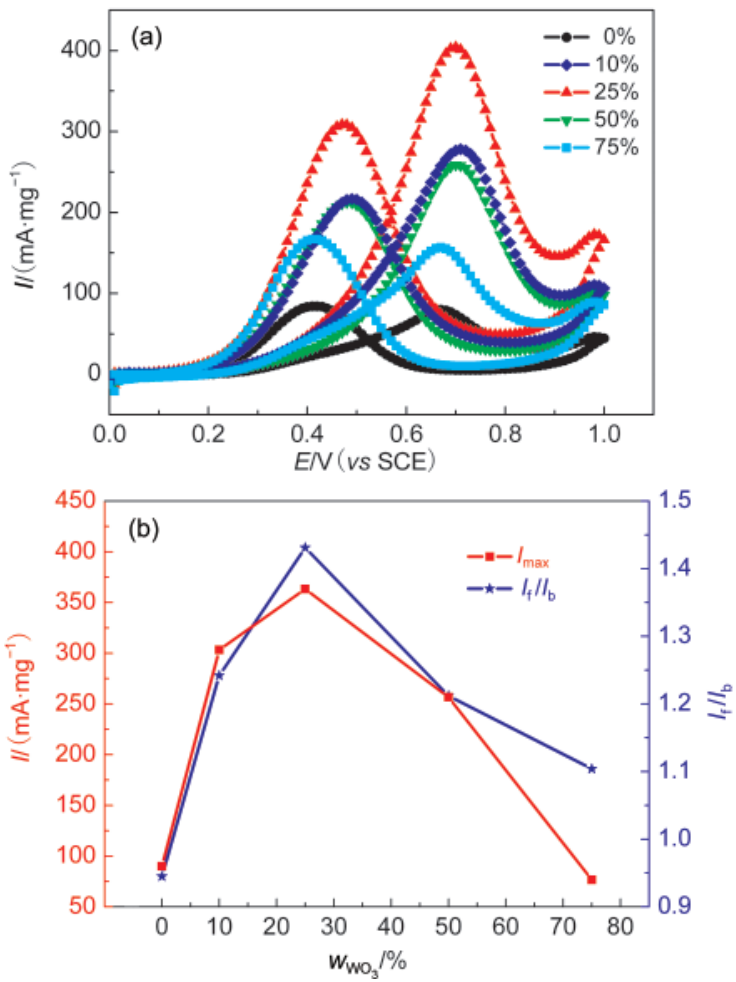

Fig.8 (a) Cyclic voltammograms of the $\mathrm{Pt} / \mathrm{WO}_{3}$-CNTs catalyst with different mass contents of $\mathrm{WO}_{3}$ in $0.5 \mathrm{~mol} \cdot \mathrm{L}^{-1} \mathrm{H}_{2} \mathrm{SO}_{4}+1.0 \mathrm{~mol} \cdot$

$\mathrm{L}^{-1} \mathrm{CH}_{3} \mathrm{OH}$ solution with a scan rate of $50 \mathrm{mV} \cdot \mathrm{s}^{-1} ;$ (b) dependency of anodic peak current density and the ratio of $I_{t} / I_{b}$ to the mass fraction of $\mathrm{WO}_{3}$

ing of $\mathrm{WO}_{3}$ amount would lead to a decrease of the electrode conductivity, thus decreases the reaction performance of $\mathrm{Pt} / \mathrm{WO}_{3}$ CNTs catalyst on the contrary, finally, the content of $\mathrm{WO}_{3}$ is optimized at ca $25 \%$.

$\mathrm{CO}$-stripping voltammograms is measured and the characteristic CO stripping curves of $\mathrm{Pt} / \mathrm{WO}_{3}-\mathrm{CNTs}$ and $\mathrm{Pt} / \mathrm{CNTs}$ catalysts are shown in Fig.9. The onset potential and the peak potential may directly reflect the $\mathrm{CO}$ oxidizing ability of the catalysts. It is revealed that the onset potential and the peak potential for the oxidation of adsorbed $\mathrm{CO}$ on $\mathrm{Pt} / \mathrm{WO}_{3}$-CNTs (Fig.9 (a)) are much lower than those on Pt/CNTs (Fig.9(b)), so $\mathrm{WO}_{3}$ 


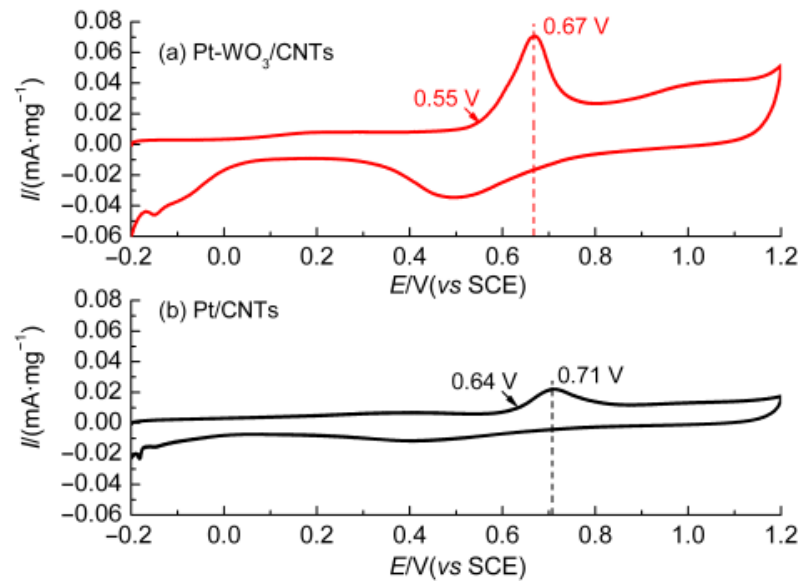

Fig.9 CO-stripping voltammograms of $\mathrm{Pt} / \mathrm{WO}_{3}-\mathrm{CNTs}$ and $\mathrm{Pt} / \mathrm{CNTS}$ catalysts in $0.5 \mathrm{~mol} \cdot \mathrm{L}^{-1} \mathrm{H}_{2} \mathrm{SO}_{4}$ solution at room temperature and a scan rate of $50 \mathrm{mV} \cdot \mathrm{s}^{-1}$

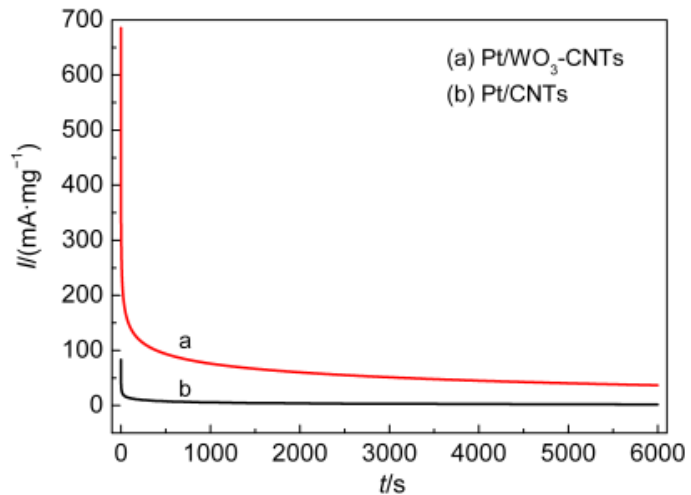

Fig.10 Chronoamperomtric curve of $\mathrm{Pt} / \mathrm{CNTs}$ and $\mathrm{Pt} / \mathrm{WO}_{3}$-CNTs in $0.5 \mathrm{~mol} \cdot \mathrm{L}^{-1} \mathrm{H}_{2} \mathrm{SO}_{4}+1 \mathrm{~mol} \cdot \mathrm{L}^{-1} \mathrm{CH}_{3} \mathrm{OH}$ solution at an operation potential of $0.7 \mathrm{~V}$

efficiently reduces the overpotential of $\mathrm{CO}$ oxidation due to forming $\mathrm{H}_{x} \mathrm{WO}_{3}-\mathrm{OH}_{\text {ads }}$ species at lower potentials, which is helpful to oxidize $\mathrm{CO}_{\text {ads }}$ through bi-functional mechanism. ${ }^{33}$

The chronoamperometry (CA) curves for the three catalysts are shown in Fig.10. These curves reflect the activity and stability of the catalysts to catalyze methanol oxidation. Obviously, the decay in the methanol oxidation current with time varies. But after $100 \mathrm{~min}$ the current density of $\mathrm{Pt} / \mathrm{WO}_{3}$-CNTs catalyst is 15 times higher than that of Pt/CNTs catalyst. It shows that the modification of $\mathrm{WO}_{3}$ can effectively improve the resistance to toxic and stability of Pt-based catalyst for methanol oxidation. This significant improvement in the catalytic performance of the $\mathrm{Pt} / \mathrm{WO}_{3}-\mathrm{CNT}$ catalysts may be attributed to three factors: first, the $\mathrm{Pt}$ and $\mathrm{WO}_{3}$ particles supported on the carbon are smaller and more uniformly distributed; second, more metallic $\mathrm{Pt}$ is present on $\mathrm{Pt} / \mathrm{WO}_{3}-\mathrm{CNTs}$ than on $\mathrm{Pt} / \mathrm{CNT}$ catalyst. Third, in the presence of $\mathrm{WO}_{3}$, the hydrogen adsorbed on the $\mathrm{Pt}$ spills over onto the surface of the $\mathrm{WO}_{3}$ and forms $\mathrm{H}_{x} \mathrm{WO}_{3}$, thus releasing these $\mathrm{Pt}$ active sites. Subsequently, $\mathrm{H}_{x} \mathrm{WO}_{3}$ can be readily oxidized to release hydrogen ions, electrons, and $\mathrm{WO}_{3}{ }^{34,35}$ This cyclic process will accelerate the dehydrogenation of methanol on Pt and improve the catalytic performance of meth- anol oxidation. The cyclic process on the $\mathrm{Pt} / \mathrm{WO}_{3}-\mathrm{CNTs}$ catalyst is speculated to occur as follows: $:^{33,34}$

$$
\begin{aligned}
& \mathrm{WO}_{3}+x \mathrm{Pt}-\mathrm{H} \rightarrow \mathrm{H}_{x} \mathrm{WO}_{3}+x \mathrm{Pt} \\
& \mathrm{H}_{x} \mathrm{WO}_{3}-\mathrm{OH}_{\text {ads }}+\mathrm{Pt}-\mathrm{CO}_{\text {ads }} \rightarrow \mathrm{H}_{x} \mathrm{WO}_{3}+\mathrm{Pt}+\mathrm{CO}_{2}+\mathrm{H}^{+}+\mathrm{e}^{-} \\
& \mathrm{H}_{x} \mathrm{WO}_{3} \rightarrow \mathrm{WO}_{3}+x \mathrm{H}^{+}+x \mathrm{e}^{-}
\end{aligned}
$$

\section{Conclusions}

Nano- $\mathrm{WO}_{3}$ modified carbon nanotubes were prepared by the conventional means with sodium tungstate as the precursor. Platinum supported on the $\mathrm{WO}_{3}$-modified CNTs $\left(\mathrm{Pt} / \mathrm{WO}_{3-}\right.$ CNTs) was prepared by means of microwave heating ethylene glycol method. Electrochemical analysis shows that the $\mathrm{Pt} /$ $\mathrm{WO}_{3}$-CNTs catalysts prepared exhibit excellent catalytic activity and stability for methanol electro-oxidation.

\section{References}

(1) Jung, E. H.; Jung, U. H.; Yang, T. H.; Peak, D. H.; Jung, D. H.; Kim, S. H. International Journal of Hydrogen Energy 2007, 32 , 903. doi: 10.1016/j.ijhydene.2006.12.014

(2) Li, X.; Chen, J. L.; Zhu, Z. H.; De Marco, R.; Bradley, J.; Dicks, A. Energy \& Fuels 2009, 23, 3721. doi: 10.1021/ef900203h

(3) Han, D. M.; Guo, Z. P.; Zeng, R.; Kim, C. J.; Meng, Y. Z.; Liu, H. K. International Journal of Hydrogen Energy 2009, 34, 2426. doi: 10.1016/j.ijhydene.2008.12.073

(4) Corpuz, A. R.; Olson, T. S.; Joghee, P.; Pylypenko, S.; Dameron, A. A.; Dinh, H. N.; O'Neill, K. J.; Hurst, K. E.; Bender, G.; Gennett, T.; Pivovar, B. S.; Richards, R. M.; O'Hayre, R. P. Journal of Power Sources 2012, 217, 142. doi: 10.1016/j.jpowsour.2012.06.012

(5) Kakati, N.; Lee, S. H.; Maiti, J.; Yoon, Y. S. Surface Science 2012, 606, 1633. doi: 10.1016/j.susc.2012.07.008

(6) Chu, Y. Y.; Wang, Z. B.; Jiang, Z. Z.; Gu, D. M.; Yin, G. P. Journal of Power Sources 2012, 203, 17. doi: 10.1016/j. jpowsour.2011.11.025

(7) Remona, A. M.; Phani, K. L. N. Journal of Fuel Cell Science and Technology 2011, 8, 011001.

(8) Chu, Y. H.; Shul, Y. G. International Journal of Hydrogen Energy 2010, 35, 11261. doi: 10.1016/j.ijhydene.2010.07.062

(9) Wu, G.; Swaidan, R.; Cui, G. F. Journal of Power Sources 2007, 172, 180. doi: 10.1016/j.jpowsour.2007.07.034

(10) Chung, Y. S.; Pak, C.; Park, G. S.; Jeon, W. S.; Kim, J. R.; Lee, Y.; Chang, H.; Seung, D. Journal of Physical Chemistry C 2008, 112, 313. doi: 10.1021/jp0759372

(11) Piela, P.; Eickes, C.; Brosha, E.; Garzon, F.; Zelenay, P. Journal of the Electrochemical Society 2004, 151, A2053.

(12) Profeti, L. P. R.; Profeti, D.; Olivi, P. International Journal of Hydrogen Energy 2009, 34, 2747. doi: 10.1016/j.ijhydene. 2009.01.011

(13) Zhou, C. M.; Wang, H. J.; Liang, J. H.; Peng, F.; Yu, H.; Yang, J. Chinese Journal of Catalysis 2008, 29, 1093. doi: 10.1016/ S1872-2067(09)60007-3 
(14) Frolova, L. A.; Dobrovolsky, Y. A. Russian Chemical Bulletin 2011, 60, 1101. doi: 10.1007/s11172-011-0174-z

(15) Guo, D. J.; You, J. M. Journal of Power Sources 2012, 198, 127. doi: 10.1016/j.jpowsour.2011.10.017

(16) Xu, M. W.; Gao, G. Y.; Zhou, W. J.; Zhang, K. F.; Li, H. L. Journal of Power Sources 2008, 175, 217. doi: 10.1016/j. jpowsour.2007.09.069

(17) Shen, P. K.; Chen, K. Y.; Tseung, A. C. C. Journal of the Electrochemical Society 1995, 142, L85.

(18) Shen, P. K.; Tseung, A. C. C. Journal of the Electrochemical Society 1994, 141, 3082. doi: 10.1149/1.2059282

(19) Shen, P. K.; Chen, K. Y.; Tseung, A. C. C. Journal of the Chemical Society-Faraday Transactions 1994, 90, 3089. doi: 10.1039/ft9949003089

(20) Cui, X. Z.; Shi, J. L.; Chen, H. R.; Zhang, L. X.; Guo, L. M.; Gao, J. H.; Li, J. B. Journal of Physical Chemistry B 2008, 112, 12024.

(21) Jayaraman, S.; Jaramillo, T. F.; Baeck, S. H.; McFarland, E. W. Journal of Physical Chemistry B 2005, 109, 22958. doi: 10.1021/jp053053h

(22) Zhang, D. Y.; Ma, Z. F.; Wang, G. X.; Konstantinov, K.; Yuan, X. X.; Liu, H. K. Electrochemical and Solid State Letters 2006, 9, A423.

(23) Chen, K. Y.; Shen, P. K.; Tseung, A. C. C. Journal of the Electrochemical Society 1995, 142, L185.

(24) Shen, P. K.; Chen, K. Y.; Tseung, A. C. C. Journal of Electroanalytical Chemistry 1995, 389, 223. doi: 10.1016/ 0022-0728(95)03974-L
(25) Yang, C. Z.; van der Laak, N. K.; Chan, K. Y.; Zhang, X. Electrochimica Acta 2012, 75, 262. doi: 10.1016/j.electacta. 2012.04.107

(26) Cui, Z. M.; Feng, L. G.; Liu, C. P.; Xing, W. Journal of Power Sources 2011, 196, 2621. doi: 10.1016/j.jpowsour.2010.08.118

(27) Rajesh, B.; Karthik, V.; Karthikeyan, S.; Thampi, K. R.; Bonard, J. M.; Viswanathan, B. Fuel 2002, 81, 2177. doi: 10.1016/ S0016-2361(02)00162-X

(28) Sheng, J. F.; Ma, C. A.; Zhang, C.; Li, G. H. Acta PhysicoChimica Sinica 2007, 23, 181. [盛江峰, 马淳安, 张 诚, 李 国华. 物理化学学报, 2007, 23, 181.] doi: 10.3866/PKU. WHXB20070209

(29) Rajeswari, J.; Viswanathan, B.; Varadarajan, T. K. Materials Chemistry and Physics 2007, 106, 168. doi: 10.1016/j. matchemphys.2007.05.032

(30) Ahmadi, R.; Amini, M. K. International Journal of Hydrogen Energy 2011, 36, 7275. doi: 10.1016/j.ijhydene.2011.03.013

(31) Raghuveer, V.; Viswanathan, B. Journal of Power Sources 2005, 144, 1. doi: 10.1016/j.jpowsour.2004.11.033

(32) Su, F. B.; Poh, C. K.; Tian, Z. G.; Xu, G. W.; Koh, G. Y.; Wang, Z.; Liu, Z. L.; Lin, J. Y. Energy \& Fuels 2010, 24, 3727. doi: $10.1021 / \mathrm{ef} 901275 \mathrm{q}$

(33) Park, K. W.; Choi, J. H.; Sung, Y. E. Journal of Physical Chemistry B 2003, 107, 5851. doi: 10.1021/jp0340966

(34) Tseung, A. C. C.; Chen, K. Y. Catalysis Today 1997, 38, 439. doi: 10.1016/S0920-5861(97)00053-9

(35) Ye, J. L.; Liu, J. G.; Zou, Z. G.; Gu, J.; Yu, T. Journal of Power Sources 2010, 195, 2633. doi: 10.1016/j.jpowsour.2009.11.055 